\title{
Spiritual Intelligence in Jaranan Turangga Yaksa Dance Art in Dongko Village, Trenggalek Regency
}

\author{
Nurpeni Priyatiningsih ${ }^{1}$ and Yoga Prambudi ${ }^{2}$ \\ \{1urpenipriyatiningsih@gmail.com, ${ }^{2}$ yogapambudi@gmail.com\} \\ ${ }^{1}$ Local Language and Letter Education Study Program of Veteran Bantara University of Sukoharjo
}

\begin{abstract}
The emergence of Jaranan Turangga Yaksa is inspired with customary ceremony called Baritan ceremony, held once a year after harvest, as the manifestation of gratitude to Almighty God. The problems of research were how the origin of story is and what spiritual intelligence is contained in Jaranan Turangga Yaksa dance art. This study was a qualitative research because the data was in writing rather than figure (number) form pertaining to spiritual intelligence in Jaranan Turangga Yaksa dance art in Dongko Village, Dongko Sub District, Trenggalek Regency. The research was conducted using sociocultural approach with descriptive qualitative research, in which data collection was not followed with the author's elaboration and perspective, so that it described a problem or phenomenon as the way it is. This research discussed the origin of story and the spiritual intelligence in Jaranan Turangga Yaksa dance art. Jaranan Turangga Yaksa art was created to recall Baritan (bubar ngarit tanduran customary ceremony) has been extinct. It is because story and movement of dance were consistent with Baritan rite, starting from the farmers leaving the farm, doing some activities, through expressing their gratitude to Almighty God. All of these were expressed in Jaranan Turangga Yaksa dance. Spiritual intelligence (spiritual quotient) contained in jaranan Turangga Yaksa dance was the manifestation of people's gratitude to Almighty God and to Dhadhung Awuk for giving fertility to the plant and abundant cattle products.
\end{abstract}

Kata Kunci: Kecerdasan Spiritual, Kesenian, Tari

\section{Introduction}

Indonesia is a state with a variety of local cultures [14]. It is because of so many islands existing throughout archipelago. Each of areas has its own culture in Indonesia. Therefore, Indonesia is well-known for its cultural vocabulary and diversity[ 1]. Wherever human beings live, there a culture is created [7]. Culture is dynamic in nature, meaning it always changes following human development [2]. The development of culture involves some elements: religious system, societal system, or social organization, knowledge system, language, art, livelihood system or economic system, and life tool and technology system [6]. Culture and art are divided into many types. They are, among others, music, dance, drama, fine art, and etc [9]. 
Art is a human's conscious activity to create physical shape directly and harmoniously and can be a space for accommodating the creator's feeling life and can pertain to others' feeling [12]. Art is Indonesians' large wealth and therefore we should preserve the art we have to prevent it from being extinct. It will be a very big loss when the art wealth we have is extinct.

Interestingly, in Java the belief in Gods and that in ancestors are often combined (united), so that veneration to god remains to be followed with the one to ancestor spirit. Even such special rites as bersih desa, nyadran, kondangan, ruwahan and etc are still held until today as the manifestation of remembrance and respect to ancestor despite the belief in God the One and Only.

Gratitude to ancestor and Almighty God is often manifested into dance. The form of dance is the beauty of human spirit expressed into body movement that is refined with esthetics and a human's medium of expression [10]. Dance performance can be classified into two types: individual and group performances. Individual performance is the one conducted by an individual or a participant only, while the group performance is thee one conducted in group or by more than one participant [9]. In addition, gratitude can be manifested into prayers accompanied with certain tembang (song), for example, Turangga Yaksa dance.

Public is so far less aware of the story of Turangga Yaksa art containing Spiritual Quotient (SQ) values. Spiritual Quotient is the intelligence in dealing with meaning and value problems, the intelligence to put our behavior and life onto broader and richer context of meaning. This intelligence is intended to assess whether or not an individual's life action or way is more meaningful than others' [15]. Furthermore, this intelligence connects human beings to God the One and Only. Spiritual quotient is also the intelligence used to solve the life problem encountered, in which human being is required to change sorrow into high life spirit (motivation), so that sorrow can change into life happiness [4]. The one with high spiritual quotient can interpret his life positively in any problem [15]. Spiritual quotient can generate idea, energy, value, vision, and motivation to make an individual's life better [13]. Majority people currently know jaranan Turangga Yaksa art as merely an entertainment until today.

Considering the background, the problems of research are formulated as follows: 1) How is the origin of Jaranan Turangga Yaksa dance art in Dongko Village, Tenggalek Regency? And 2) how is the spiritual Quotient in Jaranan Turangga Yaksa dance art in Dongko Village, Tenggalek Regency?

\section{Method}

\subsection{Type of Research}

This study was a qualitative research. A qualitative research, according to Sumaryati is the one prioritizing not quantification based on figures into the interpretation on interaction between concepts studied empirically. Another opinion suggests that a qualitative research is the research procedure producing descriptive data in written or spoken words from persons or behaviors that are observable [8].

\subsection{Research Approach}

Research approach is an attempt of conducting research activity to acquire information with persons or aspects studied. Endraswara states that approach is the measure taken to investigate a phenomenon [3]. This research employed socio-cultural approach appropriately. Socio-cultural approach is the one related to social and cultural problem of society 


\subsection{Research Method}

Research method is the research suggesting technically the technique used in a research. The research method employed in this study was descriptive one, in which the data collecting activity was not followed with author's elaboration and perspective [3].

\subsection{Data and Data Source}

Data can be words and actions obtained from persons observed or interviewed. Data source included book, archive of personal documents and other official documents, and the visualization of Jaranan Turangga Yaksa performance.

\subsection{Technique of Collecting Data}

In collecting data, technique is a way taken to understand an object studied scientifically. Techniques of collecting data used in this study were: 1) library study, 2) interview, and 3) documentation.

\subsection{Technique of Validating Data}

Data validity and reliability were tested using triangulation techniques including: 1) source triangulation, 2) method triangulation, 3) investigator triangulation, and 4) theory triangulation [8].

\subsection{Technique of Analyzing Data}

To obtain data accuracy in this research, Moleong stated that the procedure of data analysis is to organize data involving the following stages: 1) describing, 2) analyzing, 3) interpreting, 4) evaluating, and 5) drawing a conclusion [8].

\section{Data Analysis And Discussion}

\subsection{Turangga Yaksa Dance Art}

\subsubsection{The Origin of Turangga Yaksa Dance Art}

Turangga Yaksa is a form of folk arts deriving from customary ceremony, coming from Dongko Sub District, one of subdistricts in Trenggalek Regency. The customary ceremony is called baritan (bubar ngarit tanduran) existing in mountains area of southern Trenggalek, exactly Dongko Village. The customary ceremony that has been held for tens years has begun to fade since 1965 due to G $30 \mathrm{~S}$ PKI incidence. To commemorate a form of such customary ceremony, a folk art emerges, called Turangga Yaksa [5].

By its origin, Turangga Yaksa dance art is performed every Syuro or Muharam month. This ceremony is intended to express gratitude and gratefulness to God the One and Only and to livelihood sharing god, Bathara Guru, for protecting Lembu Andhini so that the harvest can be successful. Lembu Andhini is taken care of by a deified man figure named Dhadhung Awuk. Dhadhung Awuk is believed to be an animal breeder that can understand animal language and can speak with such animals as buffalo, cow, and horse.

The performance is held on the dry rice farmland or dry field. A grandstand made of dry coarse grass, straw, coconut leaves, sugar palm leaves, and equipped with young coconut leaves (janur), banana stem and fruit, and andong puring is established on it, while its base is 
made of plaited sugar palm leaves (galar) to put on gamelan, and to be the place for langen tayup performance.

The cattle owners assemble and bring offering (sesaji) with them in the form of ambengan (tumpeng) such as mule matri and buceng sengkala. They are obliged to bring their cattle binding rope called dhadhung. In addition, village officials establish an organizing committee and provide offerings in addition to those brought by cattle owners, including jenang abang, mule metri, pulagimbal pula gringsing, tumpeng, kembang wangi, kembang boreh, buceng sengkala, brokohan, nyambung tuwuh nyiram tuwuh, paes agung and kemenyan.

\subsubsection{The Performance of Turangga Yaksa Dance Art}

The ceremony is usually held at noon, after working or at about $11.00 \mathrm{a} . \mathrm{m}$. After the cattleowner farmers and people assemble, the baritan ceremony is begun with the following order.

1. Head of Village gives welcoming speech, opens baritan ceremony, and then gives the time to pawang or dukun.

2. Pawang burns incense and spells magic formula and prayers aiming to invite the spirit of Dhadhung Awuk, the herdsman; this event is accompanied with gamelan.

3. Pawang sows (fried glutinous rice) mixed with sugar (this mix is called pulagimbal pulagringsing). Pulagimbal pulagringsing is sowed to four directions (north, east, south, and west) and on the right and the left of offering and dhadhung pile (cattle binding rope), amid the ceremony. Farmers and other people attending the ceremony encircle the dhadhung place.

4. Pawang reads the purpose and the objective of sesaji making on by one and the purpose of the performance. In this event, all equipments used should be equipped with sesaji put on the center of crowd (people attending), and then pawang reads again the prayer to ask God for mercy and safety. Thereafter, it is continued with having lunch together.

5. After the ceremony has been completed, langen tayub performance is held. Before the tayub performance, dhadhung is distributed to cattle owners and the place where dhahung pile was put formerly is used to hold the tayub performance.

\subsection{Spiritual Quotient in jaranan Turangga Yaksa Dance Art}

Spiritual quotient is human's potential ability of making an individual aware of God's domination, power, and majesty and of determining meaning, value, morality, and love to fellow living organisms, either between individuals within community or between individual and nature, environment, and God (the Creator). Because feeling to be a part of a whole, human beings can position themselves appropriately and live more positively replete with policy, peace, and happiness.

Essentially, spiritual quotient is intended to deal with and to find out the meaning of what we have done and experience in daily life, so that human beings can introspect themselves can find out their misbehavior anywhere. A well-developing spiritual quotient will be characterized with an individual's ability of being flexible and adapting to environment.

When human beings can establish a good relation with the Creator (God the One and Only), with group environment (society), and with nature, they are believed to have happiness in both physical and spiritual lives in the attempt of dealing with enemy coming from inside them, lust. Considering the story of the origin of jaranan Turangga Yaksa art, this art implies that it is important for human beings to keep close to and communicating with the Creator (God the One and Only) and establishing good relationship with fellow human beings. People's understanding on spiritual quotient in the story of jaranan Turangga Yaksa art's origin is as follows: 
1. Human beings are expected to keep grateful to God the One and Only or Livelihood Sharing God for abundant crop and for health and prolific cattle.

2. The expression of gratitude to Dhadhung awuk for taking care of cattle constituting the offspring of lembu Handini on the instruction of Bathara Guru and finally cattle breeders and rice field laborers give Dhadhung awuk food as the reward.

3. A village leader or elder conducting asceticism to get closer to and to communicate with God to look for a way out of the disaster befalling Dongko Villagers.

4. Baritan ceremonial custom is a means of establishing good relationship (silaturahmi) and of uniting the citizens, or between one human and another (social creature), between human and cattle and also plant, because they are interdependent (ecosystem).

5. Baritan ceremony also recommends the people to keep preserving living environment so that water source will keep flowing as the source of living to human beings, animal, and plant.

The content of spiritual quotient in jaranan Turangga Yaksa art is closely related to human's process of treating any life problems and conditions encountered wisely [16]/

\section{Conclusion}

Jaranan Turangga Yaksa art born and growing in Dongko Village, Trenggalek Regency comes from mountains area. The emergence of Turangga Yaksa is inspired with customary ceremony called baritan (bubar ngarit tanduran) held once a year after harvest. This ceremony is the expression of gratitude and gratefulness to livelihood sharing God or God the One and Only, for abundant crop and prolific cattle. The ceremony has been held for hundred years hereditarily. Spiritual Quotient in Jaranan Turangga Yaksa dance art includes human beings expected to keep grateful to God the One and Only or Livelihood Sharing God for abundant crop and for health and prolific cattle. It is the expression of gratitude to Dhadhung awuk for taking care of cattle constituting the offspring of lembu Handini on the instruction of Bathara Guru. Finally cattle breeders and rice field laborers give Dhadhung awuk food as the reward. A village leader or elder conducted asceticism to get closer to and to communicate with God to look for a way out of the disaster befalling Dongko Villagers. Baritan ceremonial custom is a means of establishing good relationship (silaturahmi) and of uniting the citizens, or between one human and another (social creature), between human and cattle and also plant, because they are interdependent (ecosystem).

This research is conducted to find out the spiritual quotient contained in jaranan Turangga Yaksa dance art in Dongko Village, Trenggalek Regency. Baritan customary ceremony existing in Dongko community environment formerly is a very sacred ceremony, but now it serves as an entertainment media, but the plot of Turangga Yaksa story is very educative and many positive values can be the role model in daily life. Through this research, ours students and all communities can love, appreciate, and contribute to preserving jaranan Turangga Yaksa dance art more. For that reason, this art should be teaching material. 


\section{References}

[1] Asaas Putra, S. Shanaz. 2018. Etnografi Komunikasi pada Upacara Pernikahan Betawi, Jurnal Ilmiah LISKI p.104

[2] A. Rahman.dan R. Nuryanti, 2018. Perubahan Kebudayaan Surakarta dan Yogyakarta: Analisa Paradigma Evolusi Kebudayaan. Jurnal Seuneubok Lada Vol. 5. pp. 138-152 https://ejurnalunsam.id/index.php/jsnbl/article/view/891

[3] Endraswara, Suwardi. 2017. Metode, Teori, Teknik Penelitian Kebudayaan. Yogyakarta: PustakaWidyatama.

[4] Hasan, Abdul Wahid. 2006. SQ Nabi: Aplikasi Strategi dan Model Kecerdasan Spiritual (SQ) Rasulullah di Masa Kini. Yogyakarta: IRCisoD

[5] Himawan,dkk,2007. Kesenian Turangga Yaksa Trenggalaek. Surabaya: Museum Mpu Tantular.

[6] Jalaludin Nor Hashimah dan Zaharoh Ahmad, 2011. Metodologi Penelitian Kebudayaan, Jurnal Komunikasi Malaysia. pp. 203-2019

[7] Kementrian Pelancongan dan Kebudayaan Malaysia. 2017. Dasar Kebudayaan Kebangsaan. Jurnal kemtrian Pelancongan dan Kebudayaan Malaysia. p.1

[8] Moleong, Lexy J. 2014. Metode Penelitian Kualitatif. Bandung: Rosda.

[9] Prabowo, Wahyu Santosa. 2014. Tubuh Penari dan Penciptaan Tari Jawa. Surakarta: ISI Surakarta.

[10] Setyaningsih, Dyah Purwani dkk. 2003. Kerajinan Tangan dan Kesenian SMP Kelas 2. Jakarta: Erlangga.

[11] Sitokdana.M, 2015. Digitalisasi Kebudayaan di Indonesia, Jurnal” Seminar Nasional Teknologi Informasi dan Komunikasi 2015

[12] Sudjana, Poppy dkk. 1990. Pendidikan Seni Musik Untuk SMP. Jakarta: Balai Pustaka

[13] Sukidi. 2004. Kecerdasan Spiritual. PT. Gramedia Pustaka Utama: Jakarta

[14] Y. Sugiyanta, Dzuha Hening, 2011. Game Edukasi " Ragam Budaya Sebagai Media Pembelajaran Budaya Tentang Pakaian dan Adat di Indonesia”, Jurnal Seminar Nasional Teknologi Informasi dan Komunikasi Terapan

[15] Zohar, Danar dan Ian Marshal. 2001. SQ: Memanfaatkan Kecerdasan Spiritual dalam Berfikir Integralistik dan Holistik untuk Memaknai Kehidupan. Bandung: Mizan Media Utama

[16] K. Saddhono, "Language of Coastal Communities in the Northern Coast of Central Java: Sociolinguistic Studies in Cultural Integration Maritime-Agrarian Perspective." Adv. Sci. Let. vol. 23 no. 10 pp 10054-10056, 2017 